\title{
Is Excessive Intake of Kamias Fruit (Averrhoa bilimbi) Bad for Your Heath? A Case Report and Review
}

Myra Chiang MD ${ }^{1 *}$ and Marie Rose Yabut MD $^{2}$

${ }^{1}$ West Virginia University, Department of Pediatric Nephrology, Charleston, WV

${ }^{2}$ Cardinal Santos Medical Center, Department of Obstetrics and Gynecology, Manila, Philippines

*Corresponding Author: Myra Chiang, Pediatric Nephrology, WVU, Charleston, WV.

Received date: September 11, 2020; Accepted date: September 19, 2020; Published date: September 25,2020

Citation: M Chiang, MR Yabut. (2020) Is Excessive Intake of Kamias Fruit (Averrhoa bilimbi) Bad for Your Heath? A Case Report and Review. International Journal of Clinical Case Reports and Reviews. 3(5); DOI: 10.31579/2690-4861/057

Copyright: ( 2020 Myra Chiang, This is an open-access article distributed under the terms of the Creative Commons Attribution License, which permits unrestricted use, distribution, and reproduction in any medium, provided the original author and source are credited.

\section{Abstract}

Averrhoa bilimbi belongs to the Oxalidacea family of fruits. It was introduced from tropical America but is now pantropic and is cultivated in many Asian countries including the Philippines. Its nutritional and medicinal values are well known, however, due to its high oxalate content, excessive intake can lead to acute kidney injury (AKI). We report a case of AKI after ingestion of kamias (Averrhoa bilimbi) juice. Consent was granted by the patient to share her case with the intent of raising public awareness regarding the dangers of consuming high quantity of Averrhoa bilimbi fruit.

Key words: kamias; averrhoa bilimbi; acute oxalate nephropathy

\section{Case Report}

A 65 -year- old female physician was woken up from sleep early one morning because of severe upper back pain. She was overcome by nausea, was unable to tolerate oral intake and felt weak so she got herself admitted to the hospital. She was previously healthy except for a 2-year history of palpitations, controlled by diltiazem. Her other medications included cilostazol and pravastatin which she was taking for prophylaxis against cardiovascular disease. Her regular supplements included sodium ascorbate (500 mg daily), calcium, vitamin E and flaxseed oil. She denied recent intake of NSAIDs, cephalosporins or proton pump inhibitors. There is no previous history of kidney disease or kidney stones. Family history was negative for kidney disease. On exam, her vital signs were normal including blood pressure. Physical exam was unremarkable except for signs of mild dehydration. Lab work included a CBC that was unremarkable with hemoglobin of 13.5, hematocrit of 38, WBC count of 7.5. Urinalysis demonstrated dilute urine with specific gravity of 1.005 , $\mathrm{pH}$ of $6.0,1+$ blood, negative protein, glucose, nitrite, small leukocyte esterase. Microscopic exam showed $5 \mathrm{RBC} / \mathrm{hpf}, 10 \mathrm{WBC} / \mathrm{hpf}$. Serum electrolytes were normal. BUN was mildly elevated at $22 \mathrm{mg} / \mathrm{dl}$, creatinine was elevated at $1.37 \mathrm{mg} / \mathrm{dl}$ (her baseline creatinine was 0.8 ), glucose was $89 \mathrm{mg} / \mathrm{dl}$, calcium was $9.5 \mathrm{mg} / \mathrm{dl}$, ALT was $29 \mathrm{IU} / \mathrm{L}$, AST was $30 \mathrm{IU} / \mathrm{L}$, albumin was $4.1 \mathrm{~g} / \mathrm{dl}$. Renal ultrasound demonstrated 2 normal sized kidneys with normal renal echogenicity and corticomedullary differentiation. There was no hydronephrosis or measurable calculi. Upon arrival to the hospital, she was started on IV fluid and was given a dose of omeprazole IV. Tentative diagnosis was AKI possibly due to acute allergic interstitial nephritis, however, she has not taken any new medications or supplements. Because her AKI was mild, decision was made not to perform a kidney biopsy. Supportive care was provided. Serum creatinine peaked at $1.52 \mathrm{mg} / \mathrm{dl}$ on day 4 . Patient maintained good urine output and normal blood pressure throughout hospital stay. Serum creatinine started to decrease and patient was discharged home after 5 days. Repeat serum creatinine six weeks later was down to $0.9 \mathrm{mg} / \mathrm{dl}$. The patient, being a physician herself, was not content with the lack of definitive cause of her AKI. She then recalled picking kamias fruits from the tree in her backyard and making a shake out of it. She blenderized 30 large, green Kamias fruits and mixed it with $700 \mathrm{ml}$ of ice water and added honey as sweetener. She consumed the shake/juice over 2 days. By the third day, she felt ill.

\section{Discussion}

Kamias tree, (scientific names Averrhoa bilimbi, Averrhoa obtusangula Stokes) is ubiquitous in the Philippines. It belongs to the family of Oxalidaceae. Other common names in the Philippines include Iba, Kolonanas, Kalingiwa. It is commonly called Bilimbi in other countries. Other names include Cucumber Tree, Pickle Tree, Tree Sorrel, Huang Gua Shu etc. It is a small tree, growing 5 to 12 meters high [1]. The fruit is green and edible, about $4 \mathrm{~cm}$ long, cylindrical in shape and grows in clusters (Fig.1) [1].

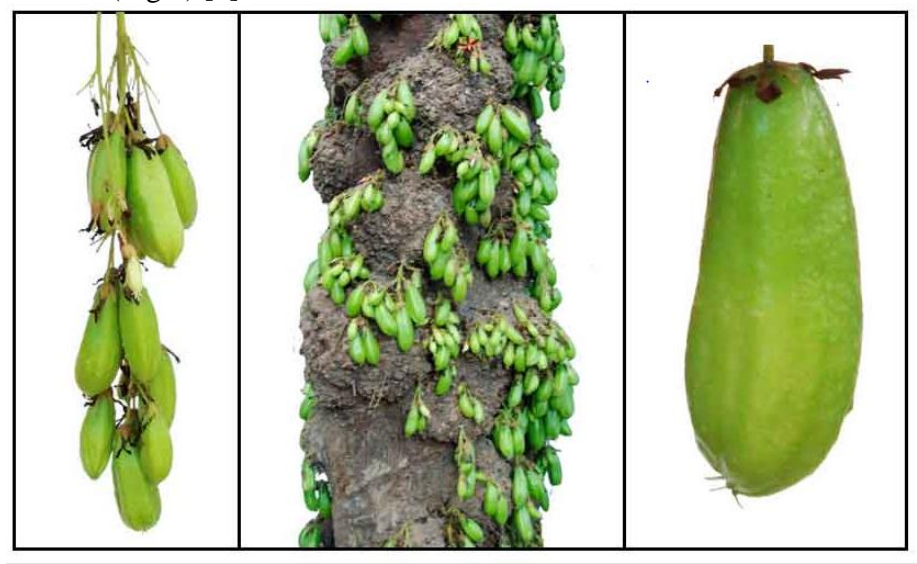

Figure 1 
It can be eaten raw. Due to its sour taste, it is prepared as a relish and food flavoring or made into sweets and jams. It is also used in making juices, vinegar, pickles and wine. It is rich in potassium, vitamins, minerals, however, it is also high in oxalic acid, ranging from 8.45 to $10.8 \mathrm{mg} / \mathrm{g}$ in ripe fruits and 10.5 and $14.7 \mathrm{mg} / \mathrm{g}$ in green fruits [1]. It is believed that Averrhoa bilimbi has hypoglycemic, hypolipidemic, antioxidant and antiatherogenic properties [1] which makes it attractive to patients with diabetes and dyslipidemia. The high oxalate load from consumption of Averrhoa bilimbi causes AKI due to deposition of calcium oxalate crystals within the renal tubules causing obstruction and acute tubular necrosis [2]. Studies in animal models also showed direct toxic effect of oxalic acid on the renal tubules and interstitium. Oxalic acid crystals stimulate connective tissue growth factor genes in the renal tubular cells leading to interstitial fibrosis [2]. Absence of calcium oxalate crystals on urinalysis or normal 24-hour urine oxalate level does not rule out acute oxalate nephropathy [3]. Almost all of reported AKI cases from acute oxalate nephropathy occurred after consuming excessive amounts of Averrhoa bilimbi in the form of juice. The consumption threshold for Averrhoa bilimbi to cause acute oxalate nephropathy is not known. It is also not known whether cooking reduces the nephrotoxicity. Case reports suggest that absorption is greater when it is ingested in a fasting state or empty stomach. Kamias trees grow widely in the Philippines. Most of the reports of AKI from Averrhoa bilimbi come from India or Bangladesh. To our surprise, despite extensive search of the literature, we did not encounter any report from the Philippines. It is highly likely that the problem is under-recognized and underreported. Neurotoxicity following ingestion of Averrhoa bilimbi in a patient with end stage kidney failure has also been reported [4], albeit not as frequent as the neurotoxicity caused by its cousin, Averrhoa carambola (balimbing or star fruit) [5]. Symptoms of neurotoxicity include uncontrollable hiccups, mental confusion and seizures $[4,5]$. Although majority of the reported cases of AKI recovered with conservative management, many required acute hemodialysis $[6,7,8,9]$. It can potentially be fatal in patients with underlying chronic kidney disease who have no access to renal replacement therapies. Our patient self- diagnosed the cause of her AKI. She is fortunate that her AKI was mild. Although she did not undergo a kidney biopsy for histologic confirmation of her diagnosis, the clear temporal association with the ingestion of the fruit suggests that consumption of kamias juice was the cause of her AKI.

\section{Conclusion}

Consumption of Kamias or Averrhoa bilimbi juice should be avoided as it can cause AKI from acute oxalate nephropathy. It can affect people with no underlying kidney disease, but patients with chronic kidney disease or diabetes, hypertension, dyslipidemia are especially vulnerable as they may have underlying undiagnosed kidney disease.

\section{References}

1. The Complete Updated List of Philippine Medicinal Plants (Sept 2020).

2. De Lima G, de Almeida M, dos Santos L (2011). Physicochemical characteristics of bilimbi (Averrhoa bilimbi). Revista Brasileira de Fruiticultura, 23(2):421-23.

3. Samad T, Haque W, Rahim M, Iqbal S, Mitra P (2017) Community acquired acute kidney injury from edible agents: report from a developing country, Bangladesh. The Open Urology and Nephrology Journal, vol 10, 20-28

4. Caetano C, de Sa C, Faleiros B, Gomes M et al (2017). Neurotoxicity following the ingestion of Averrhoa bilimbi fruit in an end stage renal disease patient on hemodialysis. Case Reports in Nephrology and Dialysis, 7:6-12.

5. Oliveira E, Aguilar A. (2015) Why eating start fruit is prohibited for patients with chronic kidney disease. J Bras Nefrol, 37 (2):241-247.

6. Billah M, Rahman A, Rahim A, Swarna A, Mitra P et al (2015). Acute kidney injury following ingestion of Averrhoa bilimbi juice. Bangladesh Crit Care J, 3 (2):71-73.

7. Nair S, George J, Kumar S Gracious N (2014) Acute oxalate nephropathy following ingestion of Averrhoa bilimbi juice. Hindawi Publishing Corp. Case Reports in Nephrology.

8. Samad T, Haque W, Rahim M, Iqbal S, Mitra P (2017) Community acquired acute kidney injury from edible agents: report from a developing country, Bangladesh. The Open Urology and Nephrology Journal, vol 10, 20-28

9. Mahamoodh Z, Vijayan S, Jojo A (2018) A case series on Averrhoa bilimbi induced acute oxalate nephropathy; an experience from a tertiary center in Kerala, India. $\mathbf{J}$ of Nephropathol, 7(4): 296-300.
This work is licensed under Creative Commons Attribution 4.0 License

To Submit Your Article Click Here: Submit Article

DOI: $10.31579 / 2690-4861 / 057$

$$
\begin{aligned}
& \text { Ready to submit your research? Choose Auctores and benefit from: } \\
& \text { fast, convenient online submission } \\
& \text { rigorous peer review by experienced research in your field } \\
& \text { rapid publication on acceptance } \\
& \text { authors retain copyrights } \\
& \text { unique DOI for all articles }
\end{aligned}
$$

At Auctores, research is always in progress.

Learn more www.auctoresonline.org/journals/international-journalof-clinical-case-reports-and-reviews 